Sādhanā Vol. 29, Part 5, October 2004, pp. 449-476. @ Printed in India

\title{
Local scour at abutments: A review
}

\author{
ABDUL KARIM BARBHUIYA ${ }^{1}$ and SUBHASISH DEY ${ }^{2 *}$ \\ ${ }^{1}$ Department of Applied Mechanics, National Institute of Technology, \\ Silchar 788 010, India \\ ${ }^{2}$ Department of Civil Engineering, Indian Institute of Technology, \\ Kharagpur 721 302, India \\ e-mail: sdey@ civil.iitkgp.ernet.in
}

MS received 5 July 2003; revised 13 August 2004

\begin{abstract}
Failure of bridges due to local scour has motivated many investigators to explore the causes of scouring and to predict the maximum scour depth at abutments. In this paper, a detailed review of the up-to-date work on scour at abutments is presented including all possible aspects, such as flow field, scouring process, parameters affecting scour depth, time-variation of scour and scour depth estimation formulae.
\end{abstract}

Keywords. Abutments; open channel flow; erosion; scour; sediment transport; hydraulics.

\section{Introduction}

Scour is a natural phenomenon caused by the erosive action of flowing stream on alluvial beds. Failure of bridges due to scour at their foundations, which consist of abutments and piers, is a common occurrence. A study of the US Federal Highway Administration in 1973 concluded that of 383 bridge failures, $25 \%$ involved pier damage and $72 \%$ involved abutment damage (Richardson et al 1993). In a report submitted to the National Roads Board of New Zealand, Sutherland (1986) pointed out that of 108 bridge failures recorded, 29 were attributed to abutment scour during 1960-1984. According to Kandasamy \& Melville (1998), 6 of 10 bridge failures that occurred in New Zealand during Cyclone Bola were related to abutment scour. In another report of the Department of Scientific and Industrial Research (DSIR) of New Zealand, Macky (1990) mentioned that about $50 \%$ of total expenditure was made towards bridge damage repairing and maintenance, out of which $70 \%$ was spent towards repairing abutment scour. Numerous equations have been developed to predict the magnitude of scour depth at abutments; and a large database of flume measurements is now available in the published literature. This paper presents a review of investigations conducted on local scour at bridge abutments. The flow field, scouring process, parameters affecting scour depth and

${ }^{*}$ For correspondence

A list of symbols is given at the end of the paper 


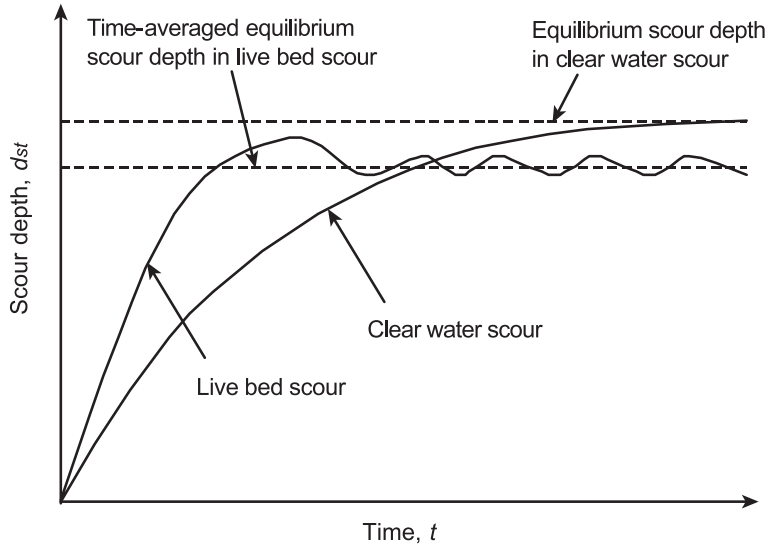

Figure 1. Time development of clearwater and live-bed scour (after Chabert \& Engeldinger 1956).

time-variation of scour are discussed in detail. Equations for predicting maximum scour depth at abutments are outlined. As scour at groynes or spur-dikes are similar to that at long and thin abutments, investigations on scour at groynes or spur-dikes are also included.

\section{Classification of local scour at abutments}

Based on the mode of sediment transport by the approaching flow, Chabert \& Engeldinger (1956) classified local scour into two categories, namely, clear-water scour and live-bed scour.

Clear-water scour takes place in the absence of sediment transport by the approaching flow into the scour hole. On the other hand, live-bed scour occurs when the scour hole is continuously fed with sediment by the approaching flow. The time-variation of clear-water and live-bed scours are shown schematically in figure 1. It was observed that maximum clearwater scour depth is approximately $10 \%$ greater than the live-bed scour depth.

\section{Flow field and bed shear stress at abutments}

The flow field at an abutment embedded vertically in a loose sediment bed of an open channel is complex in nature; and the complexity increases with the development of a scour hole involving separation of flow to form a three-dimensional vortex flow system at the base of the abutment. Though the flow field at piers has been well documented (Hjorth 1975; Melville 1975; Dey 1995; Dey et al 1995; Graf \& Istiarto 2002), research on the flow fields at groynes or spur-dikes and abutments has been limited. A brief review of investigations on flow fields at groynes or spur-dikes and abutments is given below:

Rajaratnam \& Nwachukwu (1983) measured the flow field and the shear stress at groynes placed on a planar bed. They found that the shear stress at the upstream corner of the groyne was amplified up to 5 times the approaching bed shear stress. Kwan (1988) and Kwan \& Melville (1994) identified a primary vortex, which is similar to the horseshoe vortex at piers, along with the downflow as being the principal cause of scouring at abutments. At the upstream face of an abutment, a vertical pressure gradient is developed due to stagnation of 


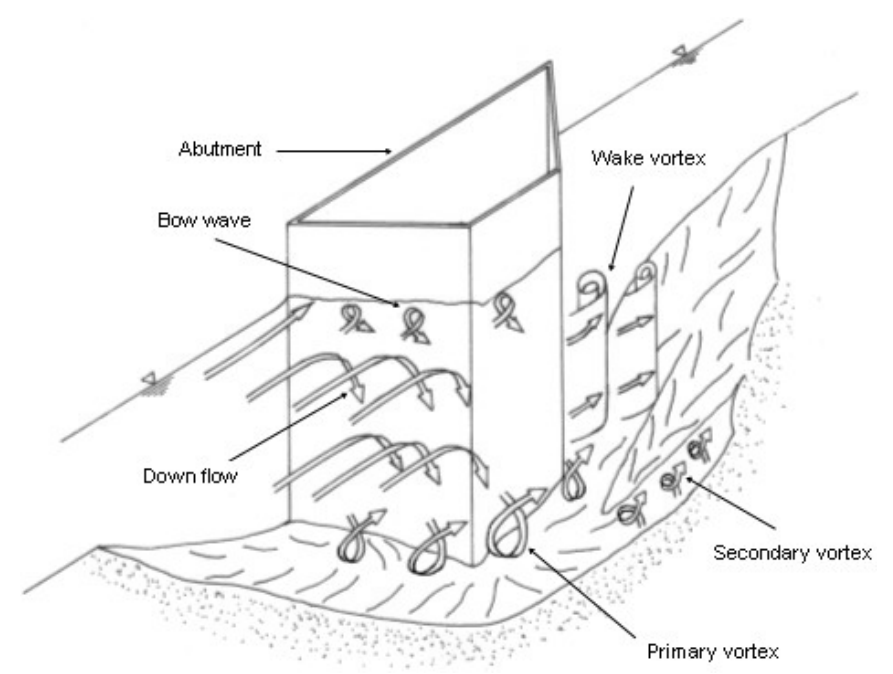

Figure 2. Schematic diagram of flow field at an abutment (after Kwan 1988).

the approaching flow. The pressure gradient drives the fluid downward and this rolls up to become the primary vortex, which enlarges its size with the development of the scour hole. Kwan \& Melville (1994) also reported that the primary vortex and the downflow are confined mainly to the scour hole beneath the original bed level. The vortex flow and the downflow are relatively unaffected with change of approaching flow depth. The inner core of the primary vortex occupies $17 \%$ of the area of the scour hole and contains up to $78 \%$ of the total circulation in the flow. The primary vortex is elliptical in shape, with an inner core region being a forced vortex and an outer core region a free vortex. The maximum velocity and downflow component in the vicinity of the abutment are 1.35 and 0.75 times of the approaching flow velocity respectively. They identified a secondary vortex, with counter-rotational direction to that of the primary vortex, occurring next to the primary vortex. The secondary vortex is believed to have the effect of restricting the scouring capacity of the primary vortex. Downstream of the abutment, wake vortices are created due to the separation of flow upstream and downstream of the abutment corners. Unstable shear layers created due to the flow separation roll up to form eddy structures, termed wake vortices. The wake vortices that drift downstream owing to the mean flow act like small tornadoes and lift up sediments from the bed. These wake vortices are rather weak compared to the primary vortex. Major flow components at a wing-wall abutment, identified by Kwan (1988), are shown schematically in figure 2 .

Molinas et al (1998) conducted experiments on vertical-wall abutments for flow Froude numbers ranging from 0.3 to 0.9 and for protrusion ratios (ratio of abutment length perpendicular to direction of flow to total channel width) of $0 \cdot 1,0 \cdot 2$ and $0 \cdot 3$. They report that shear stresses at abutments are amplified up to 10 times the bed shear stress of approaching flow and velocities are increased up to 1.5 times the approaching flow velocity, depending on the flow conditions and abutment protrusion ratios. They express the total bed shear stress as being the sum of the bed shear stresses due to the contraction and the abutment structure alone. The shear stress at the contraction is a function of the opening ratio, flow Froude number and protrusion length. On the other hand, the shear stress at the nose of the abutments is a function of 
the opening ratio and turning angle. Accordingly, they proposed the equations of bed shear stresses as

$$
\begin{aligned}
\hat{\tau}_{t} & =\hat{\tau}_{\text {cont }}+\hat{\tau}_{\text {nose }}, \\
\hat{\tau}_{\text {cont }} & =(1 / \alpha)\left[1+5 \cdot 46(1 / \alpha)^{3 \cdot 89} \mathrm{~F}_{\mathrm{r}}^{1 \cdot 74}(1 / h)^{2 \cdot 5}\right], \\
\hat{\tau}_{\text {nose }} & =\left(1 / \alpha^{2}\right)\left(1+\tan ^{2} \theta_{t}\right)^{1 / 2}-1 .
\end{aligned}
$$

Using a two-dimensional depth-averaged $k-\varepsilon$ model, Biglari \& Sturm (1998) developed a numerical model of flow at vertical-wall abutments located on the floodplain of a compound channel. The numerical results were applied in a correlation of measured equilibrium clearwater scour depth with numerical values of local velocity near the upstream corner of the abutment. According to Ahmed \& Rajaratnam (2000), the bed shear stress near the nose of the wing-wall abutment is amplified by nearly 3.63 times the bed shear stress of approaching flow. In comparison to the flow near a bridge pier, a greater skewness of velocity distributions is observed near an abutment, especially downstream. It shows the limitation of treating the abutment as a half-pier.

Flow fields at a wing-wall, semicircular and vertical-wall abutments on the plain bed were detected by Barbhuiya \& Dey (2003, 2004a), using the acoustic doppler velocimeter (ADV). Also, Barbhuiya (2003) and Barbhuiya \& Dey (2003b) measured the flow fields in scour holes at different vertical or azimuthal sections (figure 3) of vertical-wall, wing-wall and semicircular abutments. The time-averaged velocity components $(u, v, w)$ were represented

(a)

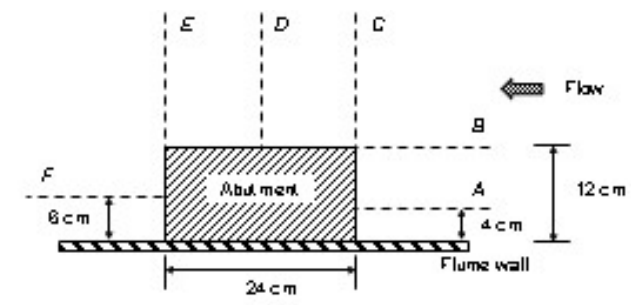

(b)

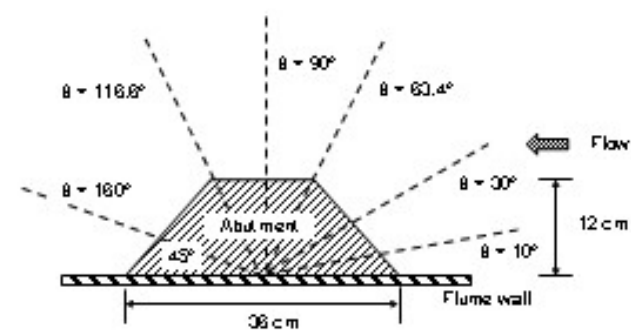

(c)

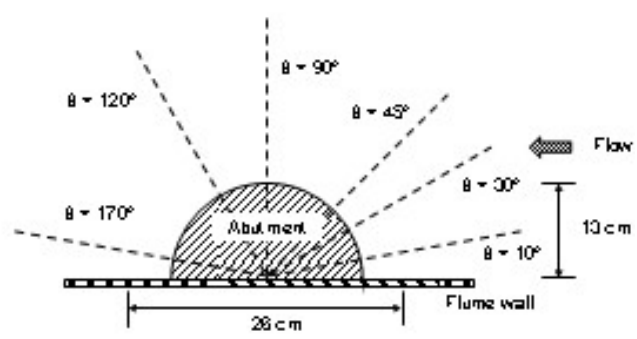

Figure 3. Sections of flow measurements (after Barbhuiya \& Dey 2003b): (a) Verticalwall abutment, (b) $45^{\circ}$ wing-wall abutment and (c) semicircular abutment. 

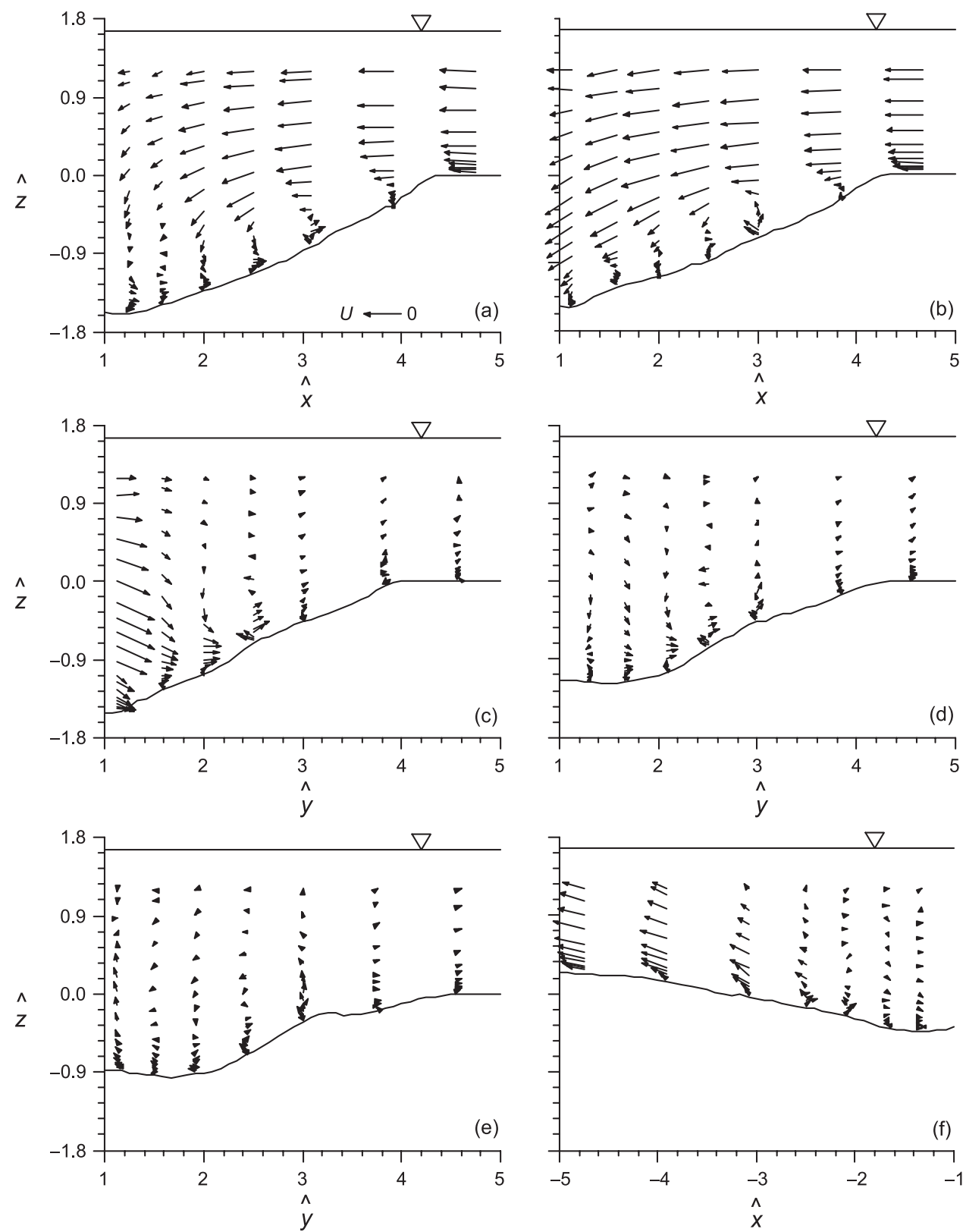

Figure 4. Normalized velocity vectors at vertical sections of a vertical-wall abutment (after Barbhuiya \& Dey 2003b): (a) $A$, (b) $B$, (c) $C$, (d) $D$, (e) $E$ and (f) $F$.

in Cartesian coordinates $(x, y, z)$ for vertical-wall abutments. On the other hand, cylindrical polar coordinates $(\theta, r, z)$ were used to represent velocity components $(u, v, w)$ for wing-wall and semicircular abutments. All linear dimensions and velocity components were normalized by the abutment length $l$ and average approaching flow velocity $U$ respectively. For verticalwall abutment, the flow fields are shown in $\hat{x} \hat{z}$ - and $\hat{y} \hat{z}$-planes at different vertical sections (figure 4); where $\hat{x}$ is $x / l, x$ is the streamwise distance, $\hat{y}$ is $y / l, y$ is the transverse distance, 

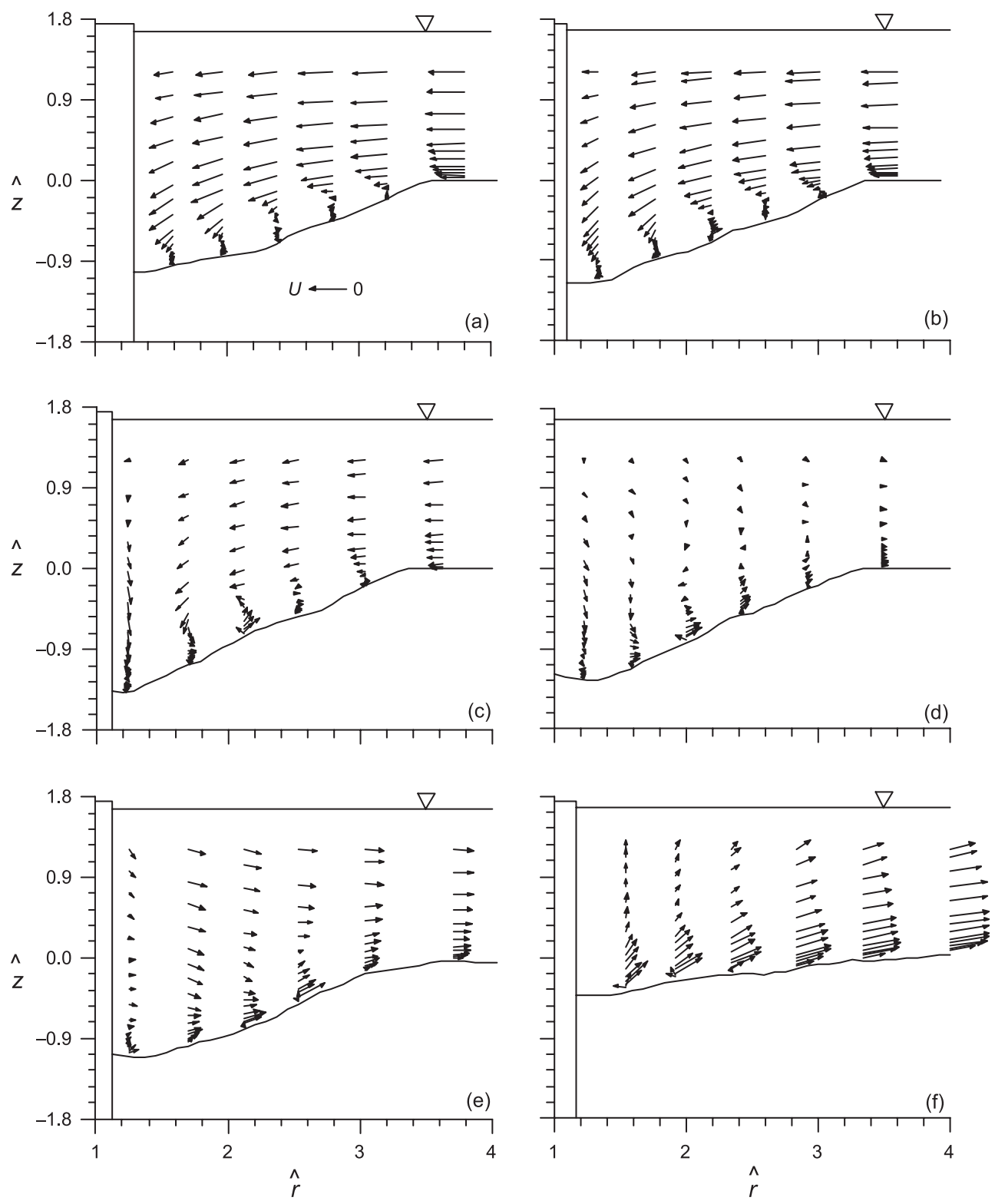

Figure 5. Normalized velocity vectors at azimuthal sections of a $45^{\circ}$ wing-wall abutment (after Barbhuiya \& Dey 2003b): $\theta=10^{\circ}(\mathbf{a}), 30^{\circ}$ (b), 63.4 (c), $90^{\circ}(\mathbf{d}), 116 \cdot 6^{\circ}$ (e) and $160^{\circ}$ (f).

$z$ is the vertical distance, and $\hat{z}$ is $z / l$. On the other hand, the flow fields are depicted in the $\hat{r} \hat{z}$-plane at different azimuthal angles $\theta$ for wing-wall and semicircular abutments (figures 5 and 6); where $\hat{r}$ is $r / l$, and $r$ is the radial distance. Observations on flow fields at vertical-wall, wing-wall and semicircular abutments are as follows (Barbhuiya \& Dey 2003b).

For vertical-wall abutment, figure 4 exhibits the normalized time-averaged velocity vectors, whose magnitudes and directions, at sections $\mathrm{A}, \mathrm{B}$ and $\mathrm{F}$, are $\left(\hat{u}^{2}+\hat{w}^{2}\right)^{1 / 2}$ and $\arctan (\hat{w} / \hat{u})$, respectively; and at sections D-E, $\left(\hat{v}^{2}+\hat{w}^{2}\right)^{1 / 2}$ and $\arctan (\hat{w} / \hat{v})$; where $\hat{u}$ is $u / U, \hat{v}$ is $v / U$, 

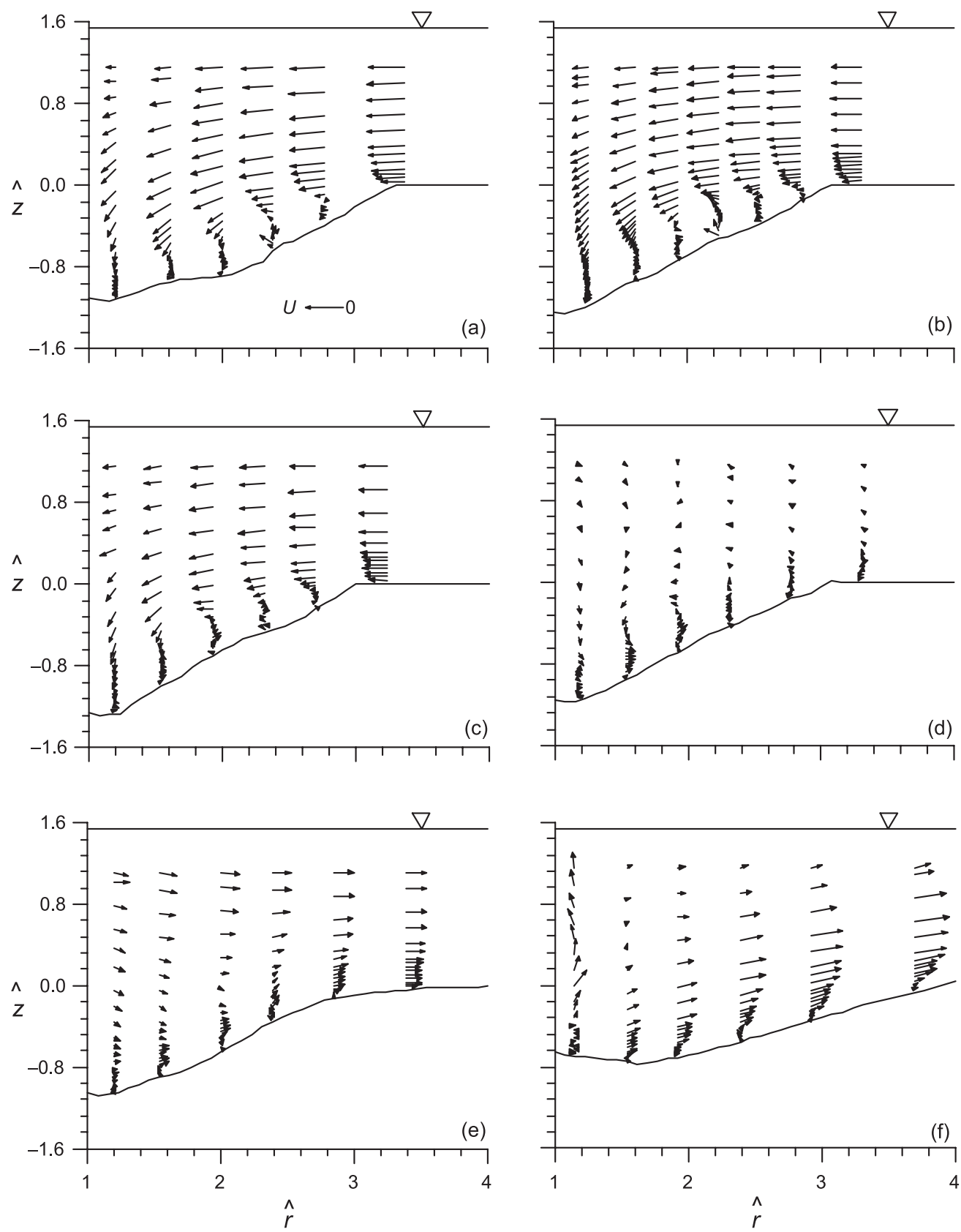

Figure 6. Normalized velocity vectors at azimuthal sections of a semicircular abutment (after Barbhuiya \& Dey 2003b): $\theta=10^{\circ}$ (a), $30^{\circ}$ (b), $45^{\circ}$ (c), $90^{\circ}$ (d), $120^{\circ}$ (e) and $170^{\circ}$ (f).

and $\hat{w}$ is $w / U$. It is evident from the flow pattern upstream of the abutment that the flow separation at the edge of the scour hole produces a reversal of the flow field inside the scour hole. This confirms a strong helicoidal flow (primary vortex) inside the scour hole upstream of the abutment. The primary vortex is strong upstream of the abutment (see sections A-C) 
and decreases by the side of the abutment (see sections D and E). In addition, the downflow at the upstream face of the abutment adds fluid to make the primary vortex stronger. To be more explicit, at the upstream face of the abutment, an adverse pressure gradient creates a downflow being returned at the base of the scour hole, showing a strong counter-clockwise vortex, which is already referred to as the primary vortex. However, at section $\mathrm{C}$, the deflection of flow at the outer edge of the abutment is prominent. At sections D and E, vortex motion is very feeble, confirming its attenuation. In the downstream (at section F), the flow field shows an upward flow near the abutment, causing suction, and further downstream, the flow directed outward becomes part of the main flow. Figures 5 and 6 display the normalized time-averaged velocity vectors at different azimuthal planes, having magnitude $\left(\hat{v}^{2}+\hat{w}^{2}\right)^{1 / 2}$ and direction $\arctan (\hat{w} / \hat{v})$, for $45^{\circ}$ wing-wall and semicircular abutments respectively. The nature of the flow field at wing-wall and semicircular abutments are almost similar, where the characteristics of the vortex flow inside the scour hole together with the downflow along the upstream face of the abutments are depicted. Circulation is strong upstream of the abutment and decreases with increase in $\theta$. At $90^{\circ}$, vortex motion is very feeble. In the downstream, the flow is directed outwards with further increase in $\theta$ beyond $90^{\circ}$. At $160^{\circ}$ (for $45^{\circ}$ wing-wall abutment) and $170^{\circ}$ (semicircular abutment), it shows an upward flow near the abutment, causing suction, and further downstream, the flow becomes part of the main flow.

\section{Parameters related to scour at abutments}

\subsection{Classification of parameters}

Parameters involved in the scour phenomenon at abutments can be grouped as follows.

(1) Parameters relating to the geometry of channel: width, cross-sectional shape and slope.

(2) Parameters relating to the abutment: size, shape, orientation with respect to main flow and surface condition.

(3) Parameters relating to the bed sediment: median size, grain size distribution, mass density, angle of repose and cohesiveness.

(4) Parameters relating to the fluid: density, viscosity, gravitational acceleration and temperature.

(5) Parameters relating to the approaching flow condition: mean flow velocity, flow depth, shear velocity and roughness.

(6) Time of scouring can be taken as an additional parameter for an evolving scour hole.

\subsection{Dimensional analyses}

Using the Buckingham p-theorem and employing physical reasoning, various investigators combined the appropriate parameters affecting the scour depth at an abutment in different nondimensional forms, which are as follows.

Garde et al (1961) gave the nondimensional parameters for scour at spur-dikes as

$$
\left(d_{s}+h\right) / h=f\left(\alpha, \theta_{a}, \mathrm{~F}_{\mathrm{r}}, C_{D}\right),
$$

where $\theta_{a}=$ angle of inclination of the spur-dike with respect to the main flow, termed angle of attack, $C_{D}=4 \Delta g d /\left(3 \rho w_{s}^{2}\right), \Delta=s-1, s=\rho_{s} / \rho$. 
Neglecting the effect of viscosity, Melville (1992) expressed the nondimensional parameters as

$$
d_{s} / l=f\left(U^{2} / g d, h / l, d / l, \sigma_{g}, K_{s}, K_{\theta}, K_{G}\right),
$$

where $\sigma_{g}=\left(d_{84} / d_{16}\right)^{0 \cdot 5}$.

Sturm \& Janjua (1994) used discharge contraction ratio instead of channel contraction ratio to analyze scour at vertical-wall abutments. They proposed a nondimentional relationship as

$$
d_{s} / h=f\left(\mathrm{~F}_{\mathrm{r}}, \mathrm{F}_{\mathrm{rc}}, M\right),
$$

where $\mathrm{F}_{\mathrm{rc}}=U_{c} /(g h)^{0.5}$, and $M=$ discharge contraction ratio, defined as the ratio of the discharge at approaching section through the opening width to the total discharge.

Lim (1997) obtained the following nondimensional parameters for scour at vertical-wall abutments neglecting the channel contraction effects:

$$
d_{s} / h=f\left(\mathrm{~F}_{\mathrm{d}}, h / d, l / h, \sigma_{g}, K_{s}, \theta_{a}, K_{G}\right) .
$$

\section{Influence of parameters on scour depth}

\subsection{Approaching flow velocity}

The effect of approaching flow velocity $U$ is incorporated in the scour predicting formulae in the form of flow Froude number $\mathrm{F}_{\mathrm{r}}$ or shear velocity $u_{*}$. Garde et al (1961), Zaghloul \& McCorquodale (1975), Zaghloul (1983), Rajaratnam \& Nwachkwu (1983) and Froehlich (1989) included the flow Froude number in their analyses. Garde et al (1961) concluded that the flow Froude number for the normal channel flow adequately represents the effect of approaching flow velocity on the maximum scour depth. Kandasamy (1989) showed that the scour depth increases with increase in flow depth due to incorporation of the flow Froude number.

It is generally recognized that the shear velocity $u_{*}$ is an important parameter not only in distinguishing clear-water scour from live-bed scour but also in representing the erosive power of the flowing stream for a given sediment size. Clear-water scour occurs for approaching flow velocity up to the critical velocity $U_{c}$ for bed sediments, that is $U / U_{c} \leq 1$; while live-bed scour occurs when $U / U_{c}>1$. For nonuniform sediments, Melville \& Sutherland (1988) defined an armor velocity $U_{a}$, which marks the transition from clear-water to livebed conditions for sediment-transporting flow and is equivalent to $U_{c}$ for uniform sediments. Thus, for nonuniform sediments, live-bed conditions prevail when $U / U_{a}>1$. However, if $U / U_{a}<1$, armoring of the bed occurs as scouring proceeds and clear-water conditions exist. Laursen (1958, 1960, 1963), Gill (1972), Wong (1982), Tey (1984), Kwan (1984), Kandasamy (1989) and Melville $(1992,1995,1997)$ considered shear velocity in their approach. Dongol (1994) conducted an extensive series of experiments to study the effect of approaching flow velocity on scour depth at vertical-wall, wing-wall and spill-through abutments under livebed conditions in uniform and nonuniform sediments. His results are complimentary to the studies of Chiew (1984) and Baker (1986) for live-bed scour at bridge piers in uniform and nonuniform sediments, respectively.

It is recognized that under clear-water conditions, the maximum scour depth occurs when $U=U_{c}$. This scour depth is called the threshold peak. For $U / U_{c}>1$, that is under livebed conditions, scour depth initially decreases with increase in approaching flow velocity 


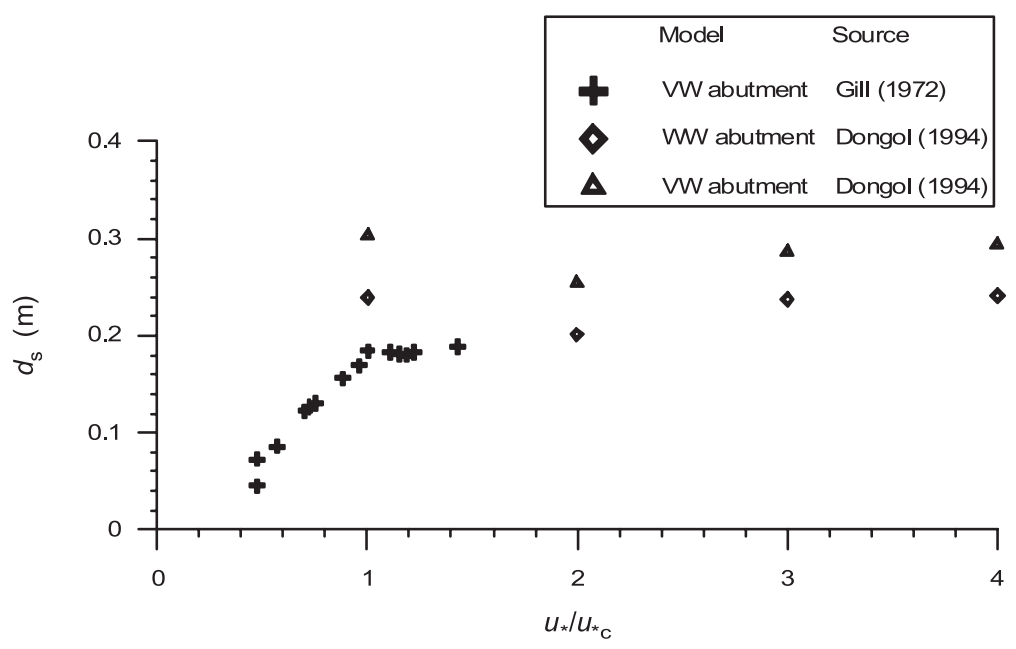

Figure 7. Variation of scour depth $d_{s}$ with shear velocity ratio $u_{*} / u_{* c}$.

reaching a minimum value and then increases again toward a second maximum. The second maximum occurs at about the transitional flatbed stage of sediment transport on the channel bed and is termed live-bed peak. Data collected from different sources are plotted in figure 7 showing the effect of shear velocity ratio $u_{*} / u_{* c}$ on scour depth.

\subsection{Approaching flow depth}

According to Laursen (1952), the approaching flow depth $h$ is an important factor to determine scour depth. Experimental results of Gill (1972), Wong (1982), Tey (1984) and Kandasamy (1989) indicate that for constant value of the shear velocity ratio $u_{*} / u_{* c}$, the maximum scour depth increases with increase in approaching flow depth. It is also observed that the maximum scour depth increases at a decreasing rate with increase in approaching flow depth. After Kandasamy (1989), for shallow flow depths, the scour depth increases proportionally with $h$, but is independent of $l$. On the other hand, for intermediate flow depths, the scour depth depends on both $h$ and $l$. However, Melville (1992) distinguished short and long abutments. He concluded that for short abutments $(l / h \geq 1)$, the scour depth is independent of flow depth; and for long abutments $(l / h \geq 25)$, the scour depth is dependent on flow depth. However, most abutments are neither long nor short, as a result of which the scour depth is influenced by both $h$ and $l$. Dey \& Barbhuiya (2004a) reported that for smaller flow depths, the equilibrium scour depth increases significantly with increase in $h$; where as for higher flow depths, equilibrium scour depth is independent of flow depth.

There is consensus that the maximum scour depth increases at a decreasing rate with increase in approaching flow depth and there exists a limiting depth corresponding to which the maximum scour depth is independent of the flow depth. Data collected from various sources are plotted in figure 8 to represent the variation of scour depth with flow depth.

\subsection{Abutment length, contraction ratio and opening ratio}

Abutment length and contraction ratio have extensively been used in formulating the maximum scour depth at abutments. The inverse of the opening ratio is termed contraction ratio. 


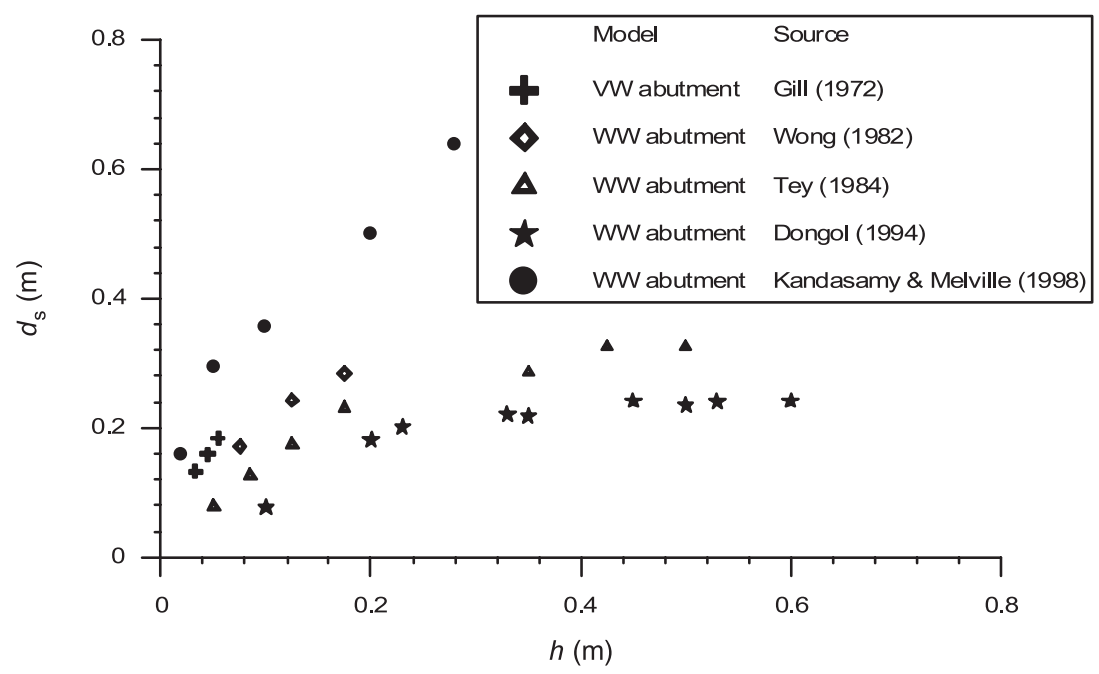

Figure 8. Variation of scour depth $d_{s}$ with flow depth $h$.

Kandasamy (1989) pointed out that if the length of the abutment is increased, the opening ratio decreases, and the effect on scour depth of such a change can be ascribed to both a decrease in contraction ratio and an increase in abutment length. Garde et al (1961), Gill (1972), Zaghloul \& McCorquodale (1975), and Rajaratnam \& Nwachukwu (1983) used contraction ratio in their analyses. Neill (1973) argued that the use of contraction ratio as a scaling parameter cannot be justified in the case of a short abutment projecting into a very wide channel, and that contraction might be regarded as a secondary influence. Extending the same argument, Neill (1973) concluded that it is logically fallacious to express the results primarily in terms of contraction ratio. Cunha (1975) found that for flow without continuous sediment motion, scour depth does not depend on the contraction ratio and is only affected by local phenomena. A similar conclusion was also drawn by Liu et al (1961) for abutments and Laursen (1963) for bridge piers and abutments.

Laursen (1963), Neill (1973), Cunha (1975), Wong (1982), Tey (1984), Kandasamy (1989), Melville (1992) and Cardoso \& Bettess (1999) advocated that scour is a local phenomenon and is independent of contraction ratio. Accordingly, abutment length has been proposed as scaling parameter. The convincing arguments are that as long as the scour hole does not extend to the opposite bank of the stream or the flume-wall, with other conditions being the same, maximum scour depth at an abutment of a fixed length is the same irrespective of the flume width or stream. A conciliatory approach would be to use contraction ratio and abutment length when the extent of the scour hole is affected and unaffected by the opposite bank or the flume-wall respectively. Figure 9 shows the dependency of equilibrium scour depth on abutment length.

\subsection{Size and gradation of sediments}

Characteristics of the bed sediments are derived from particle size distribution curves. The two most commonly used parameters are median sediment diameter $d_{50}$ (or $d$ ) and geometric standard deviation $\sigma_{g}\left[=\left(d_{84} / d_{16}\right)^{0 \cdot 5}\right]$ of particle size distribution, which is a measure of uniformity of the bed sediments. Laursen \& Toch (1956), Ahmad (1953) and Izzard 


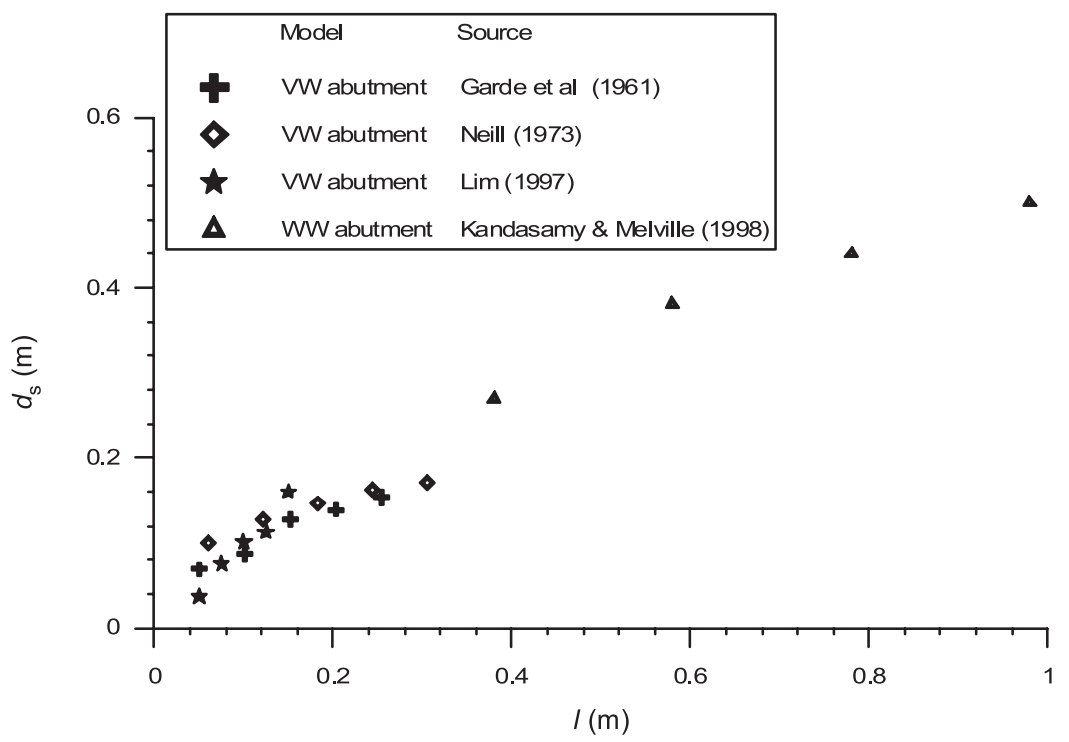

Figure 9. Variation of scour depth $d_{s}$ with abutment length $l$.

\& Bradley (1958) stated that the maximum scour depth is independent of the sediment size. Blench (1957), Garde et al (1961) and Gill (1972) reported that sediment size has an influence on the maximum scour depth. Laursen (1960) found that maximum scour depth is affected by sediment size under clear-water scour but not under live-bed scour. Results of Gill (1972) for two sediment sizes $(d=1.52 \mathrm{~mm}$ and $0.914 \mathrm{~mm})$ indicate that for the same value of $\tau_{o} / \tau_{c}<1$, scour depth is greater with coarse sediments than with fine sediments, where $\tau_{c}=$ critical shear stress for sediment particles. However, for the same value of absolute approaching bed shear stress, fine sediments produce greater scour depth. For wing-wall, spill-through and semicircular abutments, Wong (1982) found that scour depth increases with increase in bed sediment size for a constant value of $\tau_{o} / \tau_{c}$, which is close to unity.

For live-bed scour in uniform sediments, the amount of sediment being transported by the approaching flow as bed load into the scour hole and that being picked-up from the scour hole at an abutment are the same at equilibrium conditions. Since sediment size does not have any effect on the existing balance of sediment continuity, the equilibrium scour depth is unaffected by change in sediment size.

Ahmad (1953), Izzard \& Bradley (1958), Garde et al (1961) and Gill (1972) found that the rate of scour is different for different bed sediments. According to them, fine sediments are scoured at a faster rate than course sediments. Ramu (1964) observed that for the same sediment size, a change in sediment gradation $\sigma_{g}$ affects the equilibrium scour depth. Ahmad (1953) asserted that equilibrium scour depth depends on the sediment gradation $\sigma_{g}$. Ettema (1980) and Raudkivi \& Ettema (1983) found that the maximum clear-water equilibrium scour depth $d_{s}$ at a bridge pier depends on the sediment grading $\sigma_{g}$. Their proposed relationship for estimating equilibrium scour depth in nonuniform sediments in terms of the geometric standard deviation $\sigma_{g}$ is given by

$$
d_{s}\left(\sigma_{g}\right) / D=K_{\sigma} d_{s} / D
$$




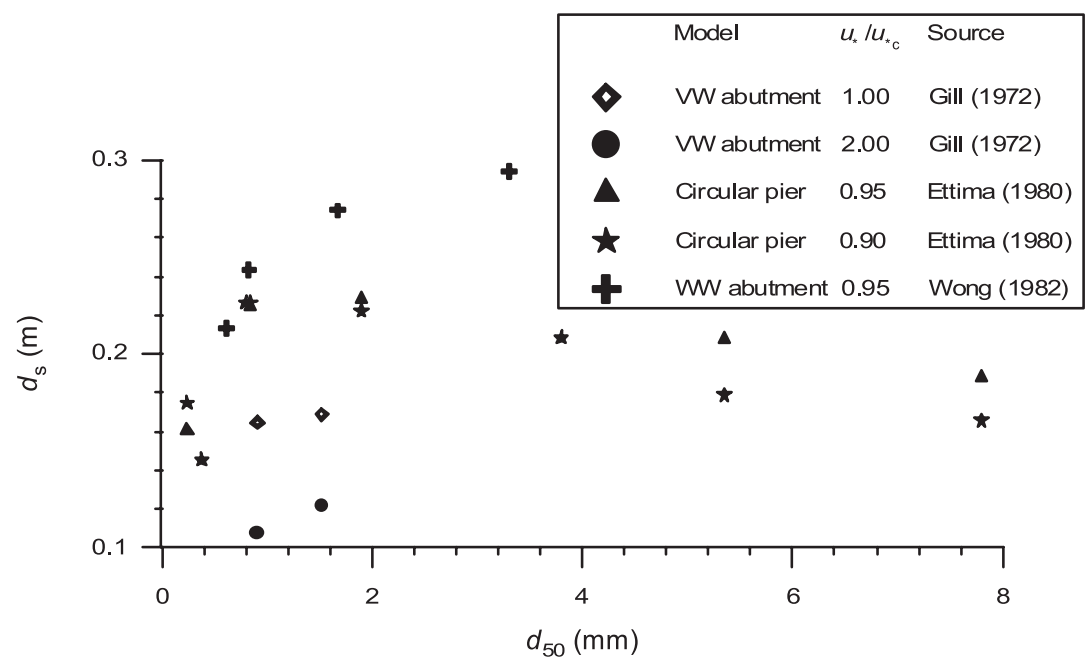

Figure 10. Variation of scour depth $d_{s}$ with sediment size $d_{50}$.

Effects of sediment sizes and gradations are shown in figures 10 and 11 respectively. According to Dey \& Barbhuiya (2004b), the effect of sediment gradation on scour depth is pronounced for nonuniform sediments, which reduces scour depth significantly due to the formation of armour-layers in scour holes.

Dey \& Barbhuiya (2004b) conducted experiments to study the effects of thinly armourlayer on scour depth at abutments. They concluded that the scour depth at an abutment with an armour-layer in clear-water scour condition under limiting stability of surface particles (approaching flow velocity nearly equaling critical velocity for threshold motion of surface particles) is always greater than that without an armour-layer for the same bed sediments.

\subsection{Abutment shape}

The shape of the abutment plays an important role on equilibrium scour depth. Streamlined bodies, such as semicircular (SC), spill-through (ST) and wing-wall (WW) abutments,

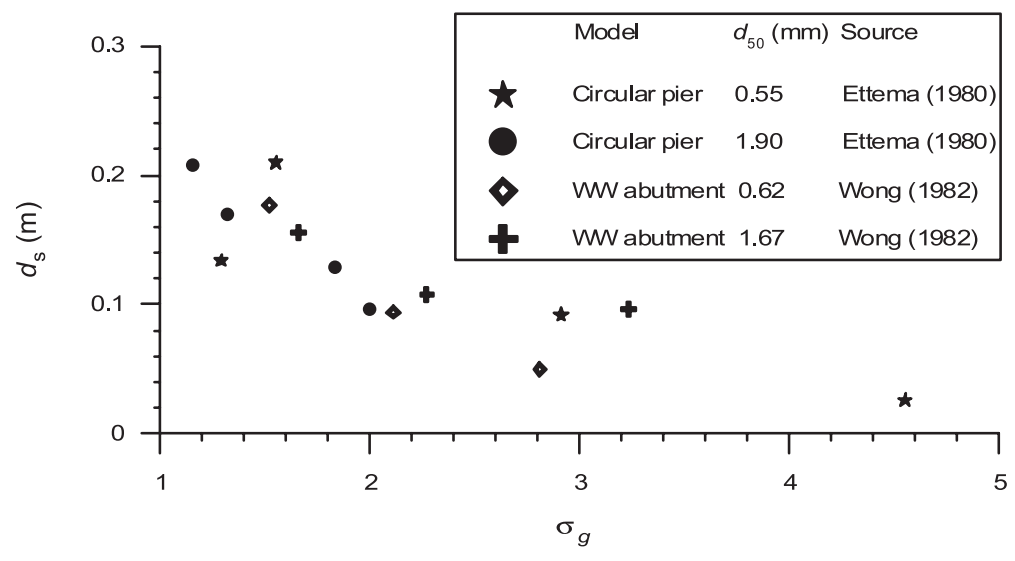

Figure 11. Variation of scour depth $d_{s}$ with sediment gradation $\sigma_{g}$. 
Table 1. Abutment shape factors.

\begin{tabular}{|c|c|c|}
\hline Abutment model & Abutment shape & Shape factor, $K_{s}$ \\
\hline & Vertical-wall & $1 \cdot 00$ \\
\hline & Semicircular ended & 0.75 \\
\hline & $45^{\circ}$ wing-wall & 0.75 \\
\hline & $\begin{array}{c}\text { Spill-through with slope } \\
\text { horizontal }: \text { vertical } \\
0 \cdot 5: 1 \\
1: 1 \\
1 \cdot 5: 1\end{array}$ & $\begin{array}{l}0.60 \\
0.50 \\
0.45\end{array}$ \\
\hline
\end{tabular}

produce vortice of feeble strength; while blunt obstructions, for example vertical-wall abutments, are capable of producing strong turbulent vortices. Consequently, a relatively large scour depth is observed at a blunt obstruction. From laboratory experimental data, Laursen \& Toch (1956), Liu et al (1961), Garde et al (1961) and Wong (1982) concluded that verticalwall abutments produce greater scour depth in comparison with spill-through and wing-wall abutments.

Melville $(1992,1995,1997)$ used shape factor $K_{s}$ to account for the effect of the shape of abutments on equilibrium scour depth. Commonly used abutment shapes and corresponding values of the shape factors are furnished in table 1 . The vertical plate is the simplest shape of an abutment and is, therefore, used as reference. For spill-through abutments, the abutment length is taken as the length at mid-depth in the flow. The shape factors given in table 1 are derived from laboratory experimental data of Gill (1972), Wong (1982), Tey (1984), Kwan (1984, 1988), Kandasamy (1989) and Dongol (1994). However, Melville (1992) asserted that the importance of abutment shape diminishes when the abutment becomes longer. Thus, for $l / h \geq 10$, an adjusted shape factor $K_{s}^{*}$ has been recommended. The adjusted shape factor $K_{s}^{*}$ varies linearly within the value of $K_{s}$ at $l / h=10$ and unity at $l / h=25$.

\subsection{Abutment alignment}

The angle of approaching flow with respect to the abutment alignment, termed angle of attack, significantly influences scour depth. It was experimentally studied by Laursen \& Toch (1956), Garde et al (1961), Zaghloul (1983) and Kwan (1984). Garde et al (1961) reported that for the same flow, sediment and abutment conditions, the maximum scour depth is greatest for a spurdike with an inclination of $90^{\circ}$. For all other inclinations the scour depth is smaller. Similar observations were also made by Kwan (1984). Zaghloul (1983) reported that the greatest equilibrium scour depth is seen for an upstream spur-dike inclination, and the smallest when 
Table 2. Flow alignment factor for different angles of attack.

\begin{tabular}{lccccc}
\hline$\theta_{a}(\mathrm{deg})$ & 30 & 60 & 90 & 120 & 150 \\
$K_{\theta}$ & 0.90 & 0.97 & 1.00 & 1.06 & 1.08 \\
\hline
\end{tabular}

the spur-dike is inclined downstream. The magnitude of the equilibrium scour depth at a spur-dike placed normal to the flow is in-between the magnitude of scour depths at spur-dikes inclined upstream and downstream. Melville (1992) included the effect of abutment alignment incorporating the alignment factor $K_{\theta}$ in the design equations. The values of $K_{\theta}$ given in table 2 were derived by the envelope curve method from the data of Ahmad (1953), Laursen (1958), Sastry (1962), Zaghloul (1983), Kwan (1984) and Kandasamy (1985). Melville (1992) recommended that the alignment factor can be applied only to longer abutments $(l / h \geq 3)$. Alignment effects are negligible for short abutments $(l / h \leq 1)$ having $K_{\theta}=1$. For abutment lengths between these two limits, a value of $K_{\theta}$ obtained from the linear interpolation has been recommended.

\subsection{Channel geometry}

Cross-sections of rivers may have different shapes depending on the geographical location, the characteristics of sediments through which they pass and the characteristics of its catchment area. Normally, in hilly regions, the cross-section of a river is parabolic with steep side slope, whereas in the plains, its cross-section is compound, with floodplains and a main channel. Thus, for bridges in the hilly region, abutments are founded in the main channel. On the other hand, for bridges in the plains, all abutments including the approach embankment may terminate in the floodplain or may extend into the main channel. Richardson \& Richardson (1998) argued that experimental results in rectangular flumes do not accurately reflect the abutment scour process in compound channels.

Froehlich (1989) considered the channel geometry effect in calculating approaching flow Froude number. He calculated the number, based on the average velocity and the depth in the area obstructed by the embankment and abutment at the approaching flow cross-section. A systematic investigation of the effect of channel geometry on scour depth at an abutment located in a compound channel, comprising floodplains and main channel, was done by Melville \& Ettema (1993) and Melville (1995). The study is limited to the case of an abutment spanning the floodplains and extending into the main channel. The effect of the channel geometry on scour depth is represented by a multiplying factor $K_{G}$, which is defined as the ratio of the scour depth at an abutment sited in a compound channel to a scour depth at an abutment sited in the corresponding rectangular channel of the same overall width as that of the compound channel and the same depth as that of the main channel of the compound section. In general, $K_{G}$ depends on the size, shape, roughness of the main channel and floodplains, and the abutment length with respect to the floodplain width. Sturm \& Janjua (1994) included discharge contraction ratio $M$ in the equation of scour depth to consider the effect of channel geometry. They demonstrated that $M$ represents the redistribution of flow between the main channel and the floodplains, as the flow passes through the bridge contraction. Cardoso \& Bettess (1999) studied the effect of channel geometry by extending the abutment length up to the edge of the main channel. Results obtained by them were in conformity with the recommendations of Melville (1995) that scour at abutments on floodplains can be approximated by the scour in rectangular channels, if an imaginary boundary is assumed separating the flow in the main 
channel and the floodplain. However, they found that the time to reach equilibrium scour, when the scour hole extends into the main channel, is shorter than that to reach equilibrium scour, when the scour hole is confined to the floodplain.

\subsection{Time-variation of scour}

Figure 1 shows a schematic diagram of the time-variation of scour depth at a cylindrical pier (after Chabert \& Engeldinger 1956). Time to reach equilibrium scour depth varies widely, ranging from a day to a fortnight. Anderson (1963) states "By virtue of the logarithmic character of the development of the scour region with time, a practical equilibrium is reached after a relatively short time, after which the increase in the depth and extent of scour becomes virtually imperceptible". Rouse (1965), however, states that scour is an ever-increasing phenomenon and there is no real equilibrium scour depth. Bresuers $(1963,1967)$ and Kohli \& Hager (2001) agree with this view. However, Laursen (1952), Carstens (1966), Gill (1972) and Zaghloul (1983) believe that an equilibrium scour depth does exist.

Rouse (1965), Gill (1972), Rajaratnam \& Nwachukwu (1983), Dargahi (1990), Ettema (1980), Kohli \& Hager (2001), Oliveto \& Hager (2002) and Coleman et al (2003) think that the variation of scour depth with time is logarithmic. Ahmad (1953), Franzetti et al (1982), Kandasamy (1989), Whitehouse (1997), Cardoso \& Bettess (1999) and Ballio \& Orsi (2000) propose an exponential time-variation of scour; while Bresuers (1967) and Cunha (1975) give a power law distribution. As per Dey \& Barbhuiya (2004b), time variation of scour depth for uniform sediments is a family of parallel lines for different abutment lengths and sediment sizes. For nonuniform sediments, time variation of scour depth reduces with increase in nonuniformity of the particle size distribution of sediments. General consensus is that equilibrium scour depth at an abutment is attained asymptotically. Data collected from different sources are plotted on a logarithmic time-scale, as shown in figure 12. Equations relating the scour depth to time for abutments are limited. The equations available in the literature are given below.

Ahmad (1953) gives an equation of time-variation of scour depth at spur-dikes as

$$
d_{s t}=d_{s}\left(1-m e^{-n t}\right) .
$$

Laursen (1963) proposes the following differential equation for the temporal development of scour depth at vertical-wall abutments:

$$
\frac{x_{d}^{3 \cdot 5}}{1-x_{d}^{1 \cdot 5}} \mathrm{~d} x_{d}=0.48 \frac{(d / h)^{1 \cdot 5}(g / h)^{0.5}}{(1 / h)^{2}\left(\tau_{o} / \tau_{c}\right)^{1 \cdot 5}} \mathrm{~d} t,
$$

where $x_{d}=d_{s t} / d_{s}$.

Cardoso \& Bettess (1999) investigated the time evaluation of scour depth at vertical-wall abutments in compound channels under steady uniform flows being close to the critical velocity for bed sediment particles. The proposed equation is given below:

$$
d_{s t} / d_{s}=1-\exp \left[-1 \cdot 025\left(t / T^{*}\right)^{0 \cdot 35}\right] .
$$

Kohli \& Hager (2001) conducted laboratory experiments to study the influence of test duration on the scour depth at vertical-wall abutments placed in floodplain. They found that the densimetric particle Froude number has a significant effect on the scour depth. They suggested a logarithmic function of time-variation of scour depth as

$$
d_{s t}=\left(\mathrm{F}_{\mathrm{d}}^{2} / 10\right)\left(h l / \cos \theta_{a}\right)^{0 \cdot 5} \log \left[t(\Delta g d)^{0 \cdot 5} / 10 h\right] .
$$




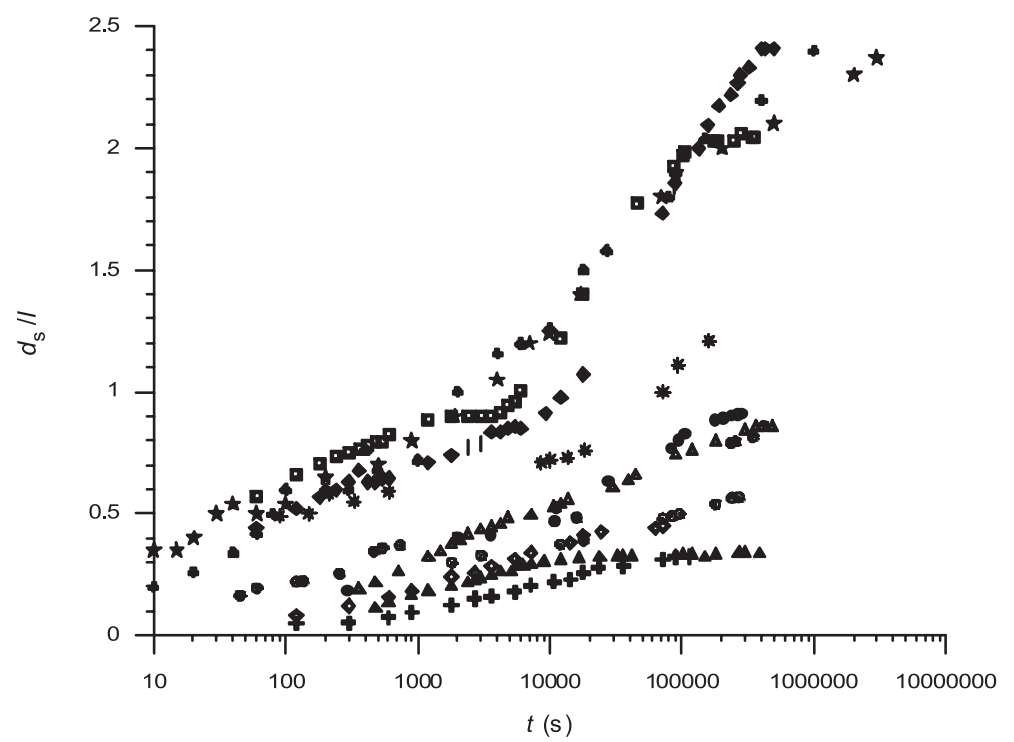

\begin{tabular}{|c|c|c|c|c|c|c|}
\hline Source & Model & $\begin{array}{c}d_{50} \\
(\mathrm{~mm})\end{array}$ & $\sigma_{\mathrm{g}}$ & $\begin{array}{c}l \\
(\mathrm{~cm}) \\
\end{array}$ & $\begin{array}{c}h \\
(\mathrm{~cm})\end{array}$ & Symbol \\
\hline \multirow[t]{2}{*}{ Wong (1982) } & \multirow[t]{2}{*}{ WW abutment } & 0.62 & 1.30 & 60 & 12.5 & + \\
\hline & & 0.83 & 1.30 & 60 & 12.5 & $\diamond$ \\
\hline \multirow[t]{2}{*}{ Kwan (1984) } & \multirow[t]{2}{*}{ SC abutment } & 0.80 & 1.28 & 63.5 & 10 & 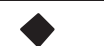 \\
\hline & & 0.85 & 1.30 & 66.5 & 5 & 口 \\
\hline \multirow{2}{*}{ Tey (1984) } & \multirow{2}{*}{ WW abutment } & 0.82 & 1.26 & 31 & 12.5 & 0 \\
\hline & & 0.82 & 1.26 & 40 & 50 & 0 \\
\hline \multirow{2}{*}{$\begin{array}{c}\text { Cardoso \& Bettess } \\
\text { (1999) }\end{array}$} & \multirow[t]{2}{*}{ VW abutment } & 0.835 & 1.26 & 27 & 2.8 & $\Delta$ \\
\hline & & 0.835 & 1.26 & 80 & 5.5 & $\Delta$ \\
\hline \multirow{2}{*}{$\begin{array}{l}\text { Balio \& Orsi } \\
\quad(2000)\end{array}$} & \multirow[t]{2}{*}{ VW abutment } & 0.82 & 1.26 & 10 & 9.2 & $\star$ \\
\hline & & 0.82 & 1.26 & 5 & 18.3 & $\leftrightarrow$ \\
\hline \multirow{2}{*}{$\begin{array}{l}\text { Kohli \& Hager } \\
\text { (2001) }\end{array}$} & \multirow[t]{2}{*}{ VW abutment } & 0.82 & 1.26 & 10 & 5.1 & * \\
\hline & & 0.82 & 1.26 & 20 & 1 & $\oplus$ \\
\hline
\end{tabular}

Figure 12. Variation of scour depth $d_{s}$ with time $t$.

The effect of approaching flow velocity, abutment length and sediment size on time-variation of scour depth at thin abutments was studied by Santos \& Cardoso (2001). Oliveto \& Hager (2002) conducted experiments to study the temporal development of scour depth at circular piers and vertical-wall abutments. They used six different sizes of uniform and nonuniform sediments including one plastic sediment. Their proposed equation of clear-water scour depth is as follows:

$$
d_{s t} / L_{R}=0.068 N_{s} \sigma_{g}^{-0.5} \mathrm{~F}_{\mathrm{d}}^{1 \cdot 5} \log \left(T_{R}\right) .
$$

$N_{s}=1.25$ for a vertical-wall abutment. 
Coleman et al (2003) analysed the time-variation of scour depth at vertical-wall abutment under clear-water condition. They put forward the following equation:

$$
d_{s t} / d_{s}=\exp \left[-0.07\left(U_{c} / U\right)|\ln (t / T)|^{1 \cdot 5}\right] .
$$

\section{Estimation of scour depth}

Equations for estimating scour depth at abutments are classified into the three following categories.

(1) Regime approach relating the scour depth to the increased discharge intensity;

(2) Empirical approach using dimensional analysis of the main parameters causing scour;

(3) Analytical or semi-empirical approach.

\subsection{Regime approach}

In the regime approach, scour depth is related to the discharge at the section under consideration.

Using Lacey's regime formula, the CBI (1949) proposed the following relationship to estimate the maximum scour depth at obstructions like spur-dikes or abutments:

$$
d_{s}+h=0.47 k_{1}\left(Q / f_{1}\right)^{1 / 3} \text { in FPS units, }
$$

( $d$ is in $\mathrm{mm}$ ), and $k_{1}$ depends on the type of obstructions (= 1 to $3 \cdot 5$ ).

Based on the laboratory experimental model studies, Ahmad (1953) suggested a relationship to estimate the maximum scour depth at spur-dikes as

$$
d_{s}+h=k_{2} q^{2 / 3},
$$

where $k_{2}$ is a constant depending on the flow intensity and angle of inclination of spur-dike.

Izzard \& Bradley (1958) proposed an equation of scour depth at spur-dikes and abutments, based on a plot of data of laboratory experimental models and prototypes as

$$
d_{s}+h=1 \cdot 4 q^{2 / 3} \text {. }
$$

The above equations have an inherent drawback for estimation of scour depth. The regime concept, originating from the analysis of general scour in live-bed conditions, was extended to local scour at spur-dikes and abutments on the basis of observations. Whereas the local scour caused by the change of flow pattern at the obstructions is fundamentally different from that of general scour, the equations indicate that the scour depth is a function of flow intensity only. However, the sediment characteristics, rate of scour and mode of sediment transport are not considered.

\subsection{Empirical approach}

In the empirical approach, parameters involved in the abutment scour are correlated through dimensional analyses. Using regression analyses of the experimental data, the equations of scour depth at abutments are developed. 
Liu et al (1961) investigated the scour at spill-through and vertical-wall abutments and suggested the following equations under clear-water scour:

$$
\begin{aligned}
& d_{s} / h=1 \cdot 1\left(\frac{l}{h}\right)^{0.4} \mathrm{~F}_{\mathrm{r}}^{0.33}+0 \cdot 3, \text { for spill-through abutments, } \\
& d_{s} / h=2 \cdot 15\left(\frac{l}{h}\right)^{0 \cdot 4} \mathrm{~F}_{\mathrm{r}}^{0.33}+0 \cdot 3, \text { for vertical-wall abutments. }
\end{aligned}
$$

Garde et al (1961) developed a relationship for the scour depth at spur-dikes under live-bed scour as

$$
\left(d_{s}+h\right) / h=\left(K_{1} / \alpha\right) \mathrm{F}_{\mathrm{r}}^{\mathrm{n}}
$$

In continuation to their work, Garde et al (1963) modified the above equation due to inherent difficulties in determining the drag coefficient $C_{D}$ and relating $K_{1}$ to $C_{D}$. The modified equation is given by

$$
\left(d_{s}+h\right) / h=4 \eta_{1} \eta_{2} \eta_{3}\left(\mathrm{~F}_{\mathrm{r}}^{\mathrm{n}} / \alpha\right) .
$$

Starting from the equation of long contraction and using experimental data, Gill (1972) derived the following generalized equation of scour depth at spur-dikes:

$$
\frac{d_{s}+h}{h}=8 \cdot 375\left(\frac{d}{h}\right)^{0 \cdot 25}\left(\frac{B}{B-l}\right)^{6 / 7}\left[\left(\frac{B}{B-l}\right)^{1 / n}\left(1-\frac{\tau_{c}}{\tau_{o}}\right)+\frac{\tau_{c}}{\tau_{o}}\right]^{-3 / 7} .
$$

In the above equation, $\tau_{o}$ is assumed to be equal to $\tau_{c}$ in live-bed scour. Gill (1972) further extended the above equation for three different flow conditions as follows:

$$
\begin{aligned}
\frac{d_{s}+h}{h}= & 8.375\left(\frac{d}{h}\right)^{0.25}\left(\frac{B}{B-l}\right)^{6 / 7}\left(\frac{\tau_{o}}{\tau_{c}}\right)^{3 / 7} \\
& \text { for clear-water scour condition }\left(\tau_{c} / \tau_{o}>0\right) \\
\frac{d_{s}+h}{h}= & 8.375\left(\frac{d}{h}\right)^{0.25}\left(\frac{B}{B-l}\right)^{(6 / 7)-(3 / 7 n)}, \\
& \text { for high sediment transport condition }\left(\tau_{c} / \tau_{o}>0\right), \\
\frac{d_{s}+h}{h}= & 8.375\left(\frac{d}{h}\right)^{0.25}\left(\frac{B}{B-l}\right)^{6 / 7}, \\
& \text { for maximum scour depth } d_{s} \text { condition }\left(\tau_{c} / \tau_{o} \approx 1\right) .
\end{aligned}
$$

In the above, $n$ varies from 1.5 to 3 .

Zaghloul \& McCorquodale (1975) presented the following equation that includes the effect of angle of inclination of spur-dike with respect to the main flow:

$$
d_{s} / h=2 \cdot 62 \mathrm{~F}_{\mathrm{r}}^{2 / 3}\left(\alpha \theta_{a}\right)^{-0 \cdot 043} .
$$


Froehlich (1989) analysed the scour data of different researchers using statistical method and developed the following equations of clear-water and live-bed scour depths:

$$
\begin{aligned}
& \frac{d_{s}}{h}=0.78 K_{s} K_{\theta}\left(\frac{l}{h}\right)^{0.63} \mathrm{~F}_{\mathrm{r}}^{1 \cdot 16}\left(\frac{h}{d}\right)^{0.43} \sigma_{g}^{-1 \cdot 87}+1, \text { for clear-water scour, } \\
& \frac{d_{s}}{h}=2.27 K_{s} K_{\theta}\left(\frac{l}{h}\right)^{0.43} \mathrm{~F}_{\mathrm{r}}^{0.61}+1, \text { for live bed scour. }
\end{aligned}
$$

The coefficient of abutment alignment $K_{\theta}$ is $\left(\theta_{a} / 90\right)^{0 \cdot 13}$. The addition of 1 at the right hand side of the equations results in large overestimation of the scour depths especially for large approaching flow depths.

Strum \& Janjua (1994) conducted the experiments in a flume with a fixed-bed main channel and a movable-bed floodplain, where the abutment terminated. Using dimensional analysis and least-square regression analysis, they derived the following equation of clear-water scour depth at abutments in floodplains:

$$
d_{s} / h=7 \cdot 7\left(\mathrm{~F}_{\mathrm{r}} / M \mathrm{~F}_{\mathrm{rc}}-0 \cdot 35\right)
$$

Melville $(1992,1995,1997)$ proposed a design method to estimate the scour depth at abutments based on empirical relationships containing different factors or coefficients. Each factor or coefficient represents the effect of flow depth, abutment size, flow intensity, sediment characteristics, abutment shape, abutment alignment and channel geometry on scour depth. The proposed equation is

$$
d_{s}=K_{h l} K_{l} K_{d} K_{s} K_{\theta} K_{G} .
$$

He argued that for short abutments $(l / h \leq 1)$, the scour depth scales with the abutment length; whereas for long abutments $(l / h \geq 25)$, the scour depth scales with the flow depth. For all other abutments $(1<l / h<25)$, the scour depth is proportional to $(h l)^{0 \cdot 5}$. Thus, according to Melville (1992), the coefficient accounting for the flow depth and abutment size is given by

$$
\begin{aligned}
& K_{h l}=2 l, \text { for } l / h \leq 1, \\
& K_{h l}=2(h l)^{0 \cdot 5}, \text { for } 1<l / h<25, \\
& K_{h l}=10 h, \text { for } l / h \geq 25 .
\end{aligned}
$$

Melville \& Sutherland (1988) presented a method for accounting sediment gradation effects including armor velocity $U_{a}$. The value of $U_{a}$ is calculated to be $0.8 U_{c n}$. The flow intensity factor, $K_{I}$ for uniform and nonuniform sediments is given by

$$
\begin{aligned}
& K_{I}=\left[U-\left(U_{a}-U_{c}\right)\right] / U_{c} \text { for }\left[U-\left(U_{a}-U_{c}\right)\right] / U_{c}<1, \\
& K_{I}=1 \text { for }\left[U-\left(U_{a}-U_{c}\right)\right] / U_{c} \geq 1 .
\end{aligned}
$$

The critical velocities $U_{c}$ and $U_{c n}$ can be determined from the logarithmic velocity distribution as

$$
\begin{aligned}
U_{c} / u_{* c} & =5.75 \log (5 \cdot 53 h / d), \\
U_{c n} / u_{* c n} & =5.75 \log \left(5.53 h / d_{50 a}\right) .
\end{aligned}
$$


The sediment size effect depends on the value of $l / d$ as given by

$$
\begin{array}{ll}
K_{d}=0 \cdot 57 \log (2 \cdot 24 l / d), & \text { for } l / d \leq 25, \\
K_{d}=1, & \text { for } l / d>25 .
\end{array}
$$

The abutment shape factor is assumed to be 1 for vertical-wall abutments and 0.75 for wingwall abutments. Spill-through abutments are assigned values of $K_{s}=0.6,0.5$ and 0.45 for $0.5: 1$ (horizontal : vertical), $1: 1$ and $1.5: 1$ side slopes, respectively. These values of shape factor apply only to shorter abutments $(l / h \leq 10)$. Shape effects were found to be unimportant for long abutments, and hence, $K_{s}=1$ for $l / h \geq 25$. For abutment lengths $10<l / h<25$, a linear interpolation has been proposed. Thus, adjusted shape factor $K_{s}^{*}$ for intermediate abutments is

$$
K_{s}^{*}=K_{s}+0 \cdot 667\left(1-K_{s}\right)[0 \cdot 1(l / h)-1] .
$$

In the above, shape factor $K_{s}$ is referred to the case $l / h \leq 10$.

The value of abutment alignment factor $K_{\theta}=1$ for an abutment aligned across the flow, that is an angle of alignment $\theta_{a}=90^{\circ}$. For $\theta_{a}<90^{\circ}$, the abutment is pointed downstream and vice versa. For alignment angles $\theta_{a}=30^{\circ}, 60^{\circ}, 120^{\circ}$ and $150^{\circ}$, the values of $K_{\theta}=0.9,0.97,1.06$ and 1.08 , respectively. Melville (1992) recommended that the alignment factor can be applied only to longer abutments $(l / h \geq 3)$. Alignment effects are negligible for short abutments, and hence, $K_{\theta}=1$ for $l / h \leq 1$. For abutment lengths $1<l / h<3$, a linear interpolation has been recommended. Thus, adjusted alignment factor $K_{\theta}^{*}$ for intermediate abutments is

$$
K_{\theta}^{*}=K_{\theta}+\left(1-K_{\theta}\right)[1 \cdot 5-0 \cdot 5(l / h)] .
$$

Channel geometry factor $K_{G}$ is defined as the ratio of the scour depth at a given abutment sited in the compound channel to that at the same abutment sited in a corresponding rectangular channel of the same overall width as that of the compound channel and the same depth as that of the main channel of the compound section. Melville \& Ettema (1993) put forward the following equation for $K_{G}$ :

$$
K_{G}=\left\{1-\left(l^{*} / l\right)\left[1-N / N^{*}\left(h^{*} / h\right)^{5 / 3}\right]\right\}^{1 / 2} .
$$

Kothyari \& Ranga Raju (2001) defined an analogous pier, with size such that scour depth at the pier is same as that at the given spur-dike or abutment under similar hydraulic conditions. Size of the analogous pier is related to the parameters that influence the drag due to the flow past spur-dike or abutment and pier, and given by Kothyari \& Ranga Raju (2001) is

$$
b_{s} / K_{s} b_{d}=0.074\left(l / b_{d}\right)^{2 \cdot 7}\left(U / \sqrt{g d \Delta \rho_{s} / \rho}\right)+0.46 .
$$

Scour depth at abutments can then be calculated using the relationships for estimation of pier scour given by Kothyari et al (1992a,b) with size of the analogous pier taken as the pier width.

Based on the field data of scour at the end of spurs in the Mississippi river, Richardson et al (2001) proposed the equation below to estimate scour depth at an abutment for live-bed scour,

$$
d_{s} / h=7 \cdot 27 K_{s} K_{\theta} \mathrm{F}_{\mathrm{r}}^{0 \cdot 33} \text {. }
$$


Richardson \& Davis (2001) recommended that (20b) and (31) are adequate for the estimation of scour depth at abutments for clear-water scour and live-bed scour conditions. Equation (11) given by Oliveto \& Hager (2002) may be applicable for the estimation of equilibrium scour depth, using a large magnitude of $T_{R}\left(\sim 10^{6}\right)$.

Recently, Dey \& Barbhuiya (2004b) put forward an equation of clear-water scour depth at short abutments as follows:

$$
d_{s} / l=5 \cdot 16 K_{s}(h / l)^{0 \cdot 18}\left(U_{c} / \sqrt{\Delta g l}\right)^{0 \cdot 26} .
$$

\subsection{Analytical or semi-empirical approach}

Laursen $(1960,1963)$ developed semi-empirical scour depth relationships for bridge abutments treating the abutment scour as a limiting case of scour through a long flow constriction. His proposed relationships for clear-water and live-bed scour depths at vertical-wall abutments as

$$
\begin{aligned}
& l / h=2 \cdot 75\left(d_{s} / h\right)\left[\left(\left(d_{s} / \hat{d}_{l} h\right)+1\right)^{1 \cdot 7}-1\right], \text { for live-bed scour, } \\
& l / h=2 \cdot 75\left(d_{s} / h\right)\left\{\left[\left[d_{s} /\left(\hat{d}_{l} h\right)+1\right]^{7 / 6} /\left(\tau_{o} / \tau_{c}\right)^{0 \cdot 5}\right]-1\right\} \text { for clear-water scour. }
\end{aligned}
$$

Laursen $(1960,1963)$ assumed $\hat{d}_{1}=12$ and 11.5 for clear-water and live-bed scour conditions, respectively.

Based on the flow continuity equation, scour geometry and a generalized power-law formula for flow resistance in alluvial channels, Lim (1997) presented a semi-empirical formula of equilibrium clear-water scour depth at an abutment as

$$
d_{s} / h=K_{s}(0.9 X-2)
$$

where $X=\theta_{c}^{-0 \cdot 375} \mathrm{~F}_{\mathrm{d}}^{0 \cdot 75}(d / h)^{0 \cdot 25}\left[0 \cdot 9(l / h)^{0 \cdot 5}+1\right]$, and $K_{s}=1$ for vertical-wall abutment and for other shapes, the values of $K_{s}$ are as given by Melville (1992). The above equation is valid up to $X=2 \cdot 22$.

Following the approach of Lim (1997), Lim \& Cheng (1998) introduced a semi-empirical equation for the time-averaged equilibrium live-bed scour at vertical-wall abutments as

$$
\left(1+\frac{d_{s}}{2 h}\right)^{4 / 3}=[1+1 \cdot 2 \sqrt{l / h}] /\left[\frac{u_{* c}^{2}}{u_{*}^{2}}+\left(\frac{l \tan \phi_{s}}{d_{s}}+1\right)^{2 / 3}\left(1-\frac{u_{* c}^{2}}{u_{*}^{2}}\right)\right]^{1 / 2} .
$$

Kandasamy \& Melville (1998) developed a relationship for maximum scour depth at piers and abutments aligned perpendicular to the flow,

$$
d_{s}=K_{s} K_{2} h^{n} l^{1-n} .
$$

In the above, $K_{2}=5$ and $n=1$ for $h / l \leq 0.04, K_{2}=1$ and $n=0.5$ for $0.04<h / l<1$, and $K_{2}=1$ and $n=0$ for $h / l>1$. 
Table 3. Scour depths estimated using equations of different investigators.

\begin{tabular}{lc}
\hline Investigator & $d_{s}(\mathrm{~m})$ \\
\hline Melville (1992) & $4 \cdot 00$ \\
Lim (1997) & $4 \cdot 03$ \\
Froehlich (1989) & $3 \cdot 88$ \\
Richardson et al (2001) & $8 \cdot 90$ \\
Oliveto \& Hager (2002) & $9 \cdot 90$ \\
Dey \& Barbhuiya (2004b) & $5 \cdot 90$ \\
\hline
\end{tabular}

\subsection{Numerical example for estimation of design scour depth}

It is rather difficult to assess the adequacy of the proposed equations for the estimation of scour depth from the point of view of design. However, from close examination of the aforementioned equations, those given by Melville (1992), Lim (1997), Richardson et al (2001), Froehlich (1989), Oliveto \& Hager (2002) and Dey \& Barbhuiya (2004b) seem to be complete. In order to compare the estimated design scour depth at a short vertical-wall abutment (aligned along the approaching flow in a rectangular channel with uniform bed sediment) using the equations of the above investigators, the following example is presented.

- Abutment length, $l=2 \mathrm{~m}$

- Approaching flow depth, $h=2.5 \mathrm{~m}$

- Uniform sediment size, $d_{50}=1 \mathrm{~mm}$

- Geometric standard deviation of particle size distribution, $\sigma_{g}=1 \cdot 1$

- Relative density of sediment particles, $s=2.65$

- Mean approaching flow velocity during flood peak, $U=0.5 \mathrm{~m} / \mathrm{s}$

- Critical approaching flow velocity, $U_{c}=0.57 \mathrm{~m} / \mathrm{s}$

Using the given data, a comparison of the estimated values of scour depth $d_{s}$ obtained from the proposed equations of Melville (1992), Lim (1997), Richardson et al (2001), Froehlich (1989), Oliveto \& Hager (2002) and Dey \& Barbhuiya (2004b) is given in table 3. It is observed that the equations of Richardson et al (2001) and Oliveto \& Hager (2002) provide conservative estimations of scour depth.

\section{Closure}

Though a large number of studies have been carried out on local scour at different abutments, and all the experimental and theoretical investigations bring us nearer to better understanding of the problem, it remains unexplored in many cases. In laboratory model studies, internal flow characteristics do not truly represent prototype bridge abutment scouring in rivers in view of large-scale distortion of the models. Also, from the available literature, it is revealed that the exact scour mechanism and effects of different parameters on scour depth are yet to be fully understood or explored. Moreover, most of the studies are restricted to uniform sediments. As natural riverbed sediments are nonuniform and at the upper reaches of hilly rivers, armouring of beds occurs due to natural sorting of bed sediments by the high flow velocity. Thus investigations on scour at abutments in nonuniform sediments and with armour-layered 
beds are important, and more of such studies are required along with field investigations on at least large-scale models.

\section{List of symbols}

$B \quad$ channel or flume width;

$b_{d} \quad$ width of cylindrical pier experiencing the same drag as that on abutment;

$b_{s} \quad$ width of analogous pier;

$C_{D} \quad$ drag coefficient of sediment particles;

$D \quad$ pier diameter;

$d, d_{50} \quad$ median diameter of sediment particles;

$d_{16} \quad 16 \%$ finer particle diameter;

$d_{50 a} \quad d_{\max } / 1 \cdot 8$

$d_{84} \quad 84 \%$ finer particle diameter;

$\hat{d}_{l} \quad$ ratio of scour depth at abutment to scour depth in equivalent long contraction;

$d_{\max } \quad$ maximum particle size of a nonuniform sediment;

$d_{s} \quad$ equilibrium scour depth in uniform sediment;

$d_{s t} \quad$ scour depth at time $t$;

$\mathrm{F}_{\mathrm{d}} \quad U /(\Delta g d)^{0 \cdot 5}$, densimetric Froude number;

$\mathrm{F}_{\mathrm{r}} \quad U /(g h)^{0.5}$, approaching flow Froude number;

$\mathrm{F}_{\mathrm{rc}} \quad U_{c} /(g h)^{0 \cdot 5}$, approaching flow Froude number corresponding to critical velocity;

$f_{1} \quad$ Lacey's slit factor, $1 \cdot 76 d^{0 \cdot 5}$;

$g \quad$ gravitational acceleration;

$h \quad$ approaching flow depth;

$h^{*} \quad$ flow depth in floodplain;

$K_{1,2}, k_{1,2} \quad$ coefficients;

$K_{d} \quad$ particle size factor;

$K_{G} \quad$ channel geometry factor;

$K_{h l} \quad$ flow depth - abutment length factor;

$K_{I} \quad$ flow intensity factor;

$K_{s}, K_{s}^{*} \quad$ abutment shape factor and adjusted abutment shape factor respectively;

$K_{\theta}, K_{\theta}^{*} \quad$ abutment alignment factor and adjusted abutment alignment factor respectively;

$K_{\sigma} \quad$ function depending on $\sigma_{g}$;

$L_{R} \quad$ reference length $l^{2 / 3} h^{1 / 3}$;

$l$ transverse length or protrusion length of abutment;

$l^{*} \quad$ width of floodplain;

$M \quad$ discharge ratio;

$m \quad$ coefficients depending on bed sediment size;

$N, N^{*} \quad$ Manning roughness coefficients for main channel and for floodplains respectively;

$N_{s} \quad$ shape number;

$n \quad$ exponents depending on bed sediment size;

$Q \quad$ design discharge;

$q \quad$ discharge intensity;

$\hat{r} \quad r / l$;

$s \quad$ relative density of sediment particles; 


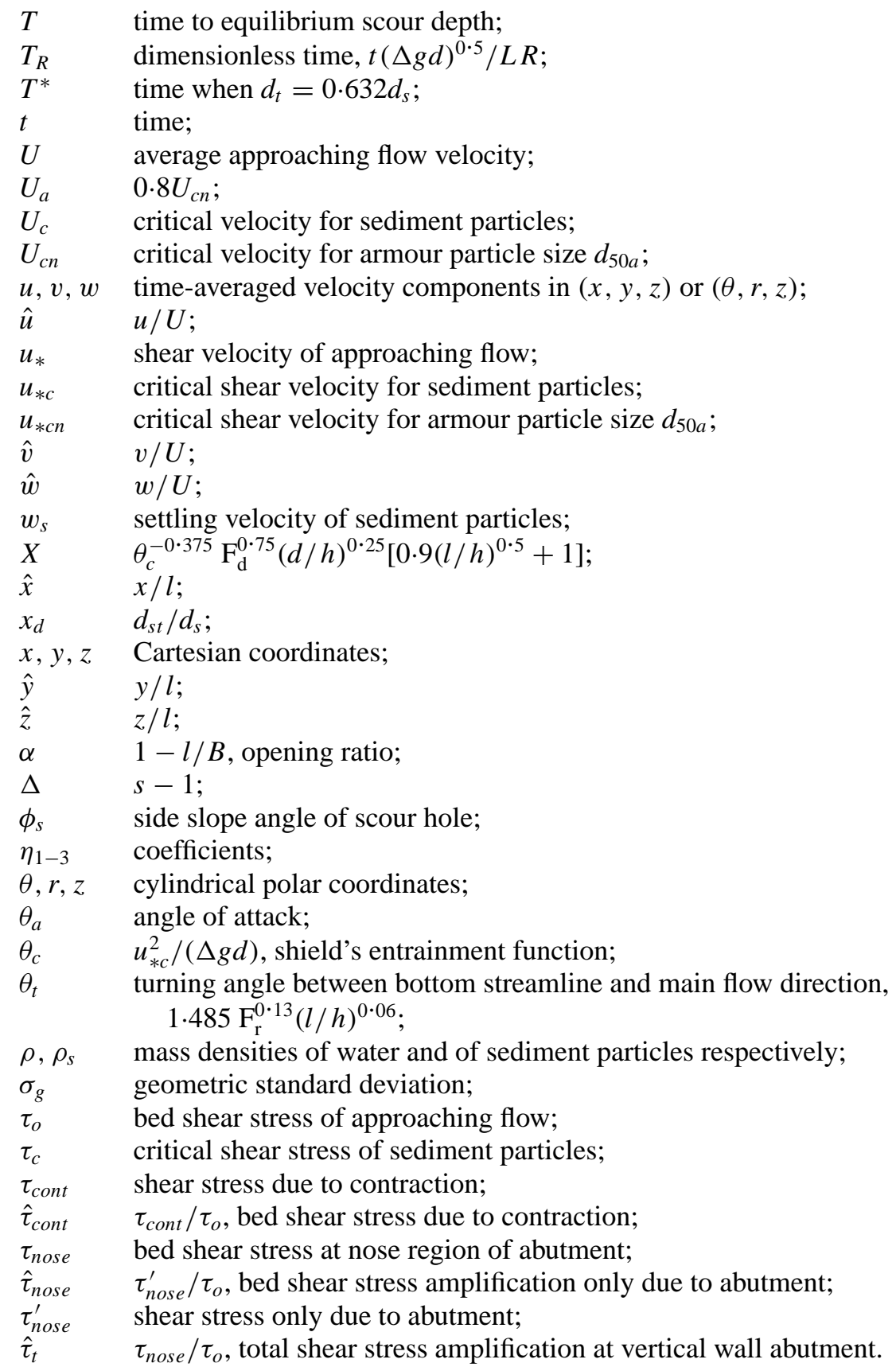

\section{References}

Ahmad M 1953 Experiments on design and behavior of spur-dikes. Proc. Int. Hydraul. Convention. : $145-159$

Ahmed F, Rajaratnam N 2000 Observations on flow around bridge abutment. J. Eng. Mech., Am. Soc. Civ. Eng. 126: 51-59 
Anderson A G 1963 Discussion of 'Sediment transportation mechanics: erosion of sediment' by Task Force on Preparation of Sedimentation Manual. J. Hydraul. Div., Am. Soc. Civ. Eng. 89: 237-248

Baker R E 1986 Local scour at bridge piers in non-uniform sediment. Rep. No. 402, School of Engineering, University of Auckland, Auckland, New Zealand

Ballio F, Orsi E 2000 Time evaluation of scour around bridge abutments. Water Eng. Res. 2: 243-259

Barbhuiya A K 2003 Clear-water scour at abutments. Ph D thesis, Department of Civil Engineering, Indian Institute of Technology, Kharagpur

Barbhuiya A K, Dey S 2003a Velocity and turbulence at a wing-wall abutment. Sādhanā 28: 35-56

Barbhuiya A K, Dey S 2003b Vortex flow field in a scour hole around abutments. Int. J. Sediment Res. 18: $1-16$

Barbhuiya A K, Dey S 2004a Measurements of turbulent flow field at a vertical semicircular cylinder attached to the sidewall of a rectangular channel. Flow Meas. Instrum. 15: 87-96

Barbhuiya A K, Dey S 2004b Turbulent flow measurement by the ADV in the vicinity of a rectangular cross-section cylinder placed at a channel sidewall. Flow Meas. Instrum. 15: 221-237

Biglari B, Sturm T W 1998 Numerical modeling of flow around bridge abutments in compound channel. J. Hydraul. Eng., Am. Soc. Civ. Eng. 124: 156-164

Blench T 1957 Regime behavior of canals and rivers (London: Butterworth Scientific)

Breusers H N C 1963 Discussion of 'Sediment transportation mechanics: erosion of sediment' by Task Force on Preparation of Sedimentation Manual. J. Hydraul. Div., Am. Soc. Civ. Eng. 89: $277-281$

Breusers H N C 1967 Time scale of two-dimensional local scour. Proc. 12th Cong. IAHR 3: 275-282

Cardoso A H, Bettess R 1999 Effects of time and channel geometry on scour at bridge abutments. $J$. Hydraul. Eng., Am. Soc. Civ. Eng. 125: 388-399

Carstens M R 1966 Similarity laws for localized scour. J. Hydraul. Div., Am. Soc. Civ. Eng. 92: 13-36

CBI 1949 Pub. No. 49, Central Board of Irrigation, New Delhi

Chabert J, Engeldinger P 1956 Etude des affouillements autour des piles de ponts. Serie A, Laboratoire National d'Hydraulique. Chatou, France (in French)

Chiew Y M 1984 Local scour at bridge piers. Ph D thesis, University of Auckland, Auckland, New Zealand

Coleman S E, Lauchlan C S, Melville B W 2003 Clear-water scour development at bridge abutments. J. Hydraul. Res. 41: 521-531

Cunha L V 1975 Time evolution of local scour. Proc. 16th Conf. Int. Assoc. Hydraulic Research (Delft: IAHR) pp 285-299

Dargahi B 1990 Controlling mechanism of local scouring. J. Hydraul. Eng., Am. Soc. Civ. Eng. 116: $1197-1214$

Dey S 1995 Three-dimensional vortex flow field around a circular cylinder in a quasi-equilibrium scour hole. Sādhanā 20: 771-785

Dey S, Barbhuiya A K 2004a Clear-water scour at abutments. Water Management, J. Proc. Inst. Civ. Eng. (London) 151: 77-97

Dey S, Barbhuiya A K 2004b Clear-water scour at abutments in thinly armored beds. J. Hydraul. Eng., Am. Soc. Civ. Eng. 130: 622-634

Dey S, Bose S K, Sastry G L N 1995 Clear-water scour at circular piers: a model. J. Hydraul. Eng., Am. Soc. Civ. Eng. 121: 869-876

Dongol D M S 1994 Local scour at bridge abutments. Rep. No. 544, School of Engineering, University of Auckland, Auckland, New Zealand

Ettema R 1980 Scour at bridge piers. Rep. No. 216, School of Engineering, University of Auckland, Auckland, New Zealand

Franzetti S, Larcan E, Mignosa P 1982 Influence of test duration on the evaluation of ultimate scour around circular piers. Proc. Int. Conf. Hydraulics and Modelling of Civil Structures, Coventry, England, pp 381-396

Froehlich D C 1989 Local scour at bridge abutments. Proc. Natl. Conf. Hydraulic Engineering (New Orleans, LA: Am. Soc. Civil Eng.) pp 13-18 
Garde R J, Subramanya K, Nambudripad K D 1961 Study of scour around spur-dikes. J. Hydraul. Div., Am. Soc. Civ. Eng. 87: 23-37

Garde R J, Subramanya K, Nambudripad K D 1963 Closure of 'Study of scour around spur-dikes'. J. Hydraul. Div., Am. Soc. Civ. Eng. 88: 167-175

Gill M A 1972 Erosion of sand beds around spur-dikes. J. Hydraul. Div., Am. Soc. Civ. Eng. 98: $1587-1602$

Graf W H, Istiarto I 2002 Flow pattern in the scour hole a around cylinder. J. Hydraul. Res. 40: 13-20

Hjorth P 1975 Studies on the nature of local scour. Bull. Series A No. 46, Department of Water Resources Engineering, University of Lund, Sweden

Kandasamy J K 1985 Local scour at skewed abutments. Rep. No. 375, School of Engineering, University of Auckland, Auckland, New Zealand

Kandasamy J K 1989 Abutment scour. Rep. No. 458, School of Engineering, University of Auckland, Auckland, New Zealand

Kandasamy J K, Melville B W 1998 Maximum local scour depth at bridge piers and abutments. J. Hydraul. Res. 36: 183-197

Kohli A, Hager W H 2001 Building scour in floodplains. Water Maritime Eng., Proc. Inst. Civ. Eng. (London) 148: 61-80

Kothyari U C, Garde R J, Ranga Raju K G 1992a Temporal variation of scour around circular bridge piers. J. Hydraul. Eng., Am. Soc. Civ. Eng. 118: 1091-1106

Kothyari U C, Garde R J, Ranga Raju K G 1992b Live-bed scour around cylindrical bridge piers. J. Hydraul. Res. 30: 701-715

Kothyari U C, Ranga Raju K G 2001 Scour around spur-dikes and bridge abutments. J. Hydraul. Res. 39: 367-374

Kwan T F 1984 Study of abutment scour. Rep. No. 328, School of Engineering, University of Auckland, Auckland, New Zealand

Kwan T F 1988 A study of abutment scour. Rep. No. 451, School of Engineering, University of Auckland, Auckland, New Zealand

Kwan T F, Melville B W 1994 Local scour and flow measurements at bridge abutments. J. Hydraul. Res. 32: 661-673

Laursen E M 1952 Observations on the nature of scour. Proc. 5th Hydraul. Conf. : 179-197

Laursen E M 1958 Scour at bridge crossings. Bull. No. 8, Iowa Highways Research Board, Ames, Iowa

Laursen E M 1960 Scour at bridge crossings. J. Hydraul. Div., Am. Soc. Civ. Eng. 86: 39-54

Laursen E M 1963 An analysis of relief bridge scour. J. Hydraul. Div., Am. Soc. Civ. Eng. 89: 93-118

Laursen E M, Toch A 1956 Scour around bridge piers and abutments. Bull. No. 4, Iowa Highways Research Board, Ames, Iowa

Lim S Y 1997 Equilibrium clear-water scour around an abutment. J. Hydraul. Eng., Am. Soc. Civ. Eng. 123: 237-243

Lim S Y, Cheng N S 1998 Prediction of live-bed scour at bridge abutments. J. Hydraul. Eng., Am. Soc. Civ. Eng. 124: 635-638

Liu H K, Chang F M, Skinner M M 1961 Effect of bridge construction on scour and backwater. CER 60 HKL 22, Colorado State University, Civil Engineering Section, Fort Collins, Colorado

Macky G H 1990 Survey of roading expenditure due to scour. CR 90.09, Department of Scientific and Industrial Research, Hydrology Centre, Christchurch, New Zealand

Melville B W 1975 Local scour at bridge sites. Rep. No. 117, School of Engineering, University of Auckland, Auckland, New Zealand

Melville B W 1992 Local scour at bridge abutments. J. Hydraul. Eng., Am. Soc. Civ. Eng. 118: 615-631

Melville B W 1995 Bridge abutment scour in compound channels. J. Hydraul. Eng., Am. Soc. Civ. Eng. 121: 863-868

Melville B W 1997 Pier and abutment scour: integrated approach. J. Hydraul. Eng., Am. Soc. Civ. Eng. 123: 125-136

Melville B W, Ettema R 1993 Bridge abutment scour in compound channels. Proc. Natl. Conf. Hydraulic Engineering, Univ. of Iowa, Iowa City, Iowa, pp 767-772 
Melville B W, Sutherland A J 1988 Design method for local scour at bridge piers. J. Hydraul. Eng., Am. Soc. Civ. Eng. 114: 1210-1226

Molinas A, Kheireldin K, Wu B 1998 Shear stress around vertical wall abutments. J. Hydraul. Eng., Am. Soc. Civ. Eng. 124: 822-830

Neill C R 1973 Guide to bridge hydraulics (Toronto: University of Toronto Press)

Oliveto G, Hager W H 2002 Temporal evolution of clear-water pier and abutment scour. J. Hydraul. Eng., Am. Soc. Civ. Eng. 128: 811-820

Rajaratnam N, Nwachukwu B A 1983 Flow near groin-like structures. J. Hydraul. Eng., Am. Soc. Civ. Eng. 109: 463-480

Ramu K L V 1964 Effect of sediment size on scour. Ph D thesis, University of Roorkee, Roorkee, India

Raudkivi A J, Ettema R 1983 Clear-water scour at cylindrical piers. J. Hydraul. Eng., Am. Soc. Civ. Eng. 109: 338-350

Richardson E V, Davis S R 2001 Evaluating scour at bridges. HEC18 FHWA NHI-001, Federal Highway Administration, US Department of Transportation, Washington, DC.

Richardson E V, Harrison L J, Richardson J R, Davies S R 1993 Evaluating scour at bridges. Publ. FHWA-IP-90-017, Federal Highway Administration, US Department of Transportation, Washington, DC

Richardson E V, Richardson J R 1998 Discussion of 'Pier and abutment scour: integrated approach' by B W Melville. J. Hydraul. Eng., Am. Soc. Civ. Eng. 124: 771-772

Richardson E V, Simons D B, Lagasse P F 2001 River engineering for highway encroachments highways in the river environment. HS6 FHWA NHI-01-004, Federal Highway Administration, US Department of Transportation, Washington, DC

Richardson J R, Richardson E V 1993 The fallacy of local abutment scour equations. Proc. Conf. Hydraul. Div. 1: 749-754

Rouse H 1965 Engineering hydraulics: sediment transportation (New York: John Wiley and Sons)

Santos J S D, Cardoso A H 2001 Time evolution of local scour at obstacles protruding from channel side walls. Int. J. Sediment Res. 16: 460-472

Sastry C L N 1962 Effect of spur-dike inclination on scour characteristics. M E thesis, University of Roorkee, Roorkee

Sturm T W, Janjua N S 1994 Clear-water scour around abutments in floodplains. J. Hydraul. Eng., Am. Soc. Civ. Eng. 120: 956-972

Sutherland A J 1986 Reports on bridge failure. RRU Occasional Paper, National Roads Board, Wellington, New Zealand

Tey C B 1984 Local scour at bridge abutments. Rep. No. 329, School of Engineering, University of Auckland, Auckland, New Zealand

Whitehouse R J S 1997 Scour at marine structures: a manual for engineers and scientists. Res. Rep. SR417, HR Wallingford Limited, Wallingford, UK

Wong W H 1982 Scour at bridge abutments. Rep. No. 275, School of Engineering, University of Auckland, New Zealand

Zaghloul N A 1983 Local scour around spur-dikes. J. Hydrol. 60: 123-140

Zaghloul N A, McCorquodale J A 1975 A stable numerical model for local scour. J. Hydraul. Res. 13: 425-444 